\title{
16. ORGANIC FACIES OF CRETACEOUS AND JURASSIC SEDIMENTS FROM DEEP SEA DRILLING PROJECT SITE 534 IN THE BLAKE-BAHAMA BASIN, WESTERN NORTH ATLANTIC ${ }^{1}$
}

\author{
Colin P. Summerhayes, ${ }^{2}$ Exxon Production Research Company, Houston, Texas \\ and \\ Theodora C. Masran, c/o S. A. J. Pocock, Esso Resources Canada Limited, 339-Fiftieth Avenue South East, \\ Calgary, Alberta, Canada T2G 2B3
}

\begin{abstract}
The organic facies of Early and middle Cretaceous sediments drilled at DSDP Site 534 is dominated by terrestrially derived plant remains and charcoal. Marine organic matter is mixed with the terrestrial components, but through much of this period was diluted by the terrestrial material. The supply of terrestrial organic matter was high here because of the nearness of the shore and high runoff promoted by a humid temperate coastal climate. Reducing conditions favored preservation of both marine and terrestrial organic matter, the terrestrial materials having reached the site mostly in turbidity currents or in the slow-moving, near-bottom nepheloid layer. An increase in the abundance of terrestrial organic matter occurred when the sea level dropped in the Valanginian and again in the Aptian-Albian, because rivers dumped more terrigenous clastics into the Basin and marine productivity was lower at these times than when sea level was high.

A model is proposed to explain the predominance of reducing conditions in the Valanginian-Aptian, of oxidizing conditions in the late Aptian, and of reducing conditions in the Albian-Cenomanian. The model involves influx of oxygen-poor subsurface waters from the Pacific at times of high or rising sea level (Valanginian-Aptian, and AlbianCenomanian) and restriction of that influx at times of low sea level (late Aptian). In the absence of a supply of oxygenpoor deep water, the bottom waters of the North Atlantic became oxidizing in the late Aptian, probably in response to development of a Mediterranean type of circulation. The influx of nutrients from the Pacific led to an increase in productivity through time, accounting for an increase in the proportion of marine organic matter from the Valanginian into the Aptian and from the Albian to the Cenomanian.

Conditions were dominantly oxidizing through the Middle Jurassic into the Berriasian, with temporary exceptions when bottom waters became reducing, as in the Callovian. Mostly terrestrial and some marine organic matter accumulated during the Callovian reducing episode. When Jurassic bottom waters were oxidizing, only terrestrial organic matter was buried in the sediments, in very small amounts.
\end{abstract}

\section{INTRODUCTION}

It is widely recognized that the types and amounts of organic matter in marine sediments are responses to the supply and preservation of organic material from marine or terrestrial sources (Arthur, 1979; Welte et al., 1979; Tissot et al., 1980; Summerhayes, 1981). Examination of the organic matter buried in marine sediments can tell us whether bottom waters were oxidizing or reducing (through good versus poor preservation of easily decomposable materials); whether the surface waters were productive or not (through the presence or absence of organic enrichment); and whether the climate of the hinterland was humid or arid (through the relative abundance of marine and terrestrial organic matter).

We have examined the distribution of organic matter in sediments recovered at DSDP Site 534, in the BlakeBahama Basin, with the following objectives in mind:

1) to determine the distribution of organic matter in Mesozoic sediments at this site (for location, see Fig. 1);

2) to determine the organic facies of these sediments;

3) to establish the probable controls on deposition of organic matter here; and

\footnotetext{
${ }^{1}$ Sheridan, R. E., Gradstein, F. M., et al., Init. Repts. DSDP, 76: Washington (U.S. Govt, Printing Office).

Present address: BP Research Center, Chertsey Road, Sunbury-on-Thames, Middlesex TW 16 7LN, United Kingdom.
}

4) to relate our findings to the deposition of organic matter in the Mesozoic at other sites in the western North Atlantic (Fig. 1), and to draw inferences about paleocirculation and climate.

In many respects this study is a follow-up to earlier work on the nature and controls of deposition of the organic facies of the mid-Cretaceous "black shales" that are widespread throughout the deep North Atlantic (Summerhayes, 1981). It is also a part of Exxon's ongoing program of studies on the nature and origin of organic matter in deep-sea sediments (McIver and Rogers, 1978; Johnson et al., 1979; Gilbert et al., 1980; Gilbert and Summerhayes, 1981, in press; Summerhayes and Gilbert, 1982, in press). This site is particularly interesting in that Jurassic "black shales" were recovered, along with the anticipated mid-Cretaceous ones. These are the first organic-rich Jurassic sediments recovered from deep water by DSDP in the North Atlantic.

\section{TYPES AND AMOUNTS OF ORGANIC MATTER}

The drilled section consists of several different geologic units, each with a characteristic lithology (Table 1). Shipboard geochemical reports by Sheridan, Gradstein, et al. (Site 534 report, this volume) and postcruise studies by Herbin et al. (this volume), confirm that the different units tend to have different organic facies, as explained in the next sections. Our data (Table 2) supplement the shipboard reports but are less comprehen- 


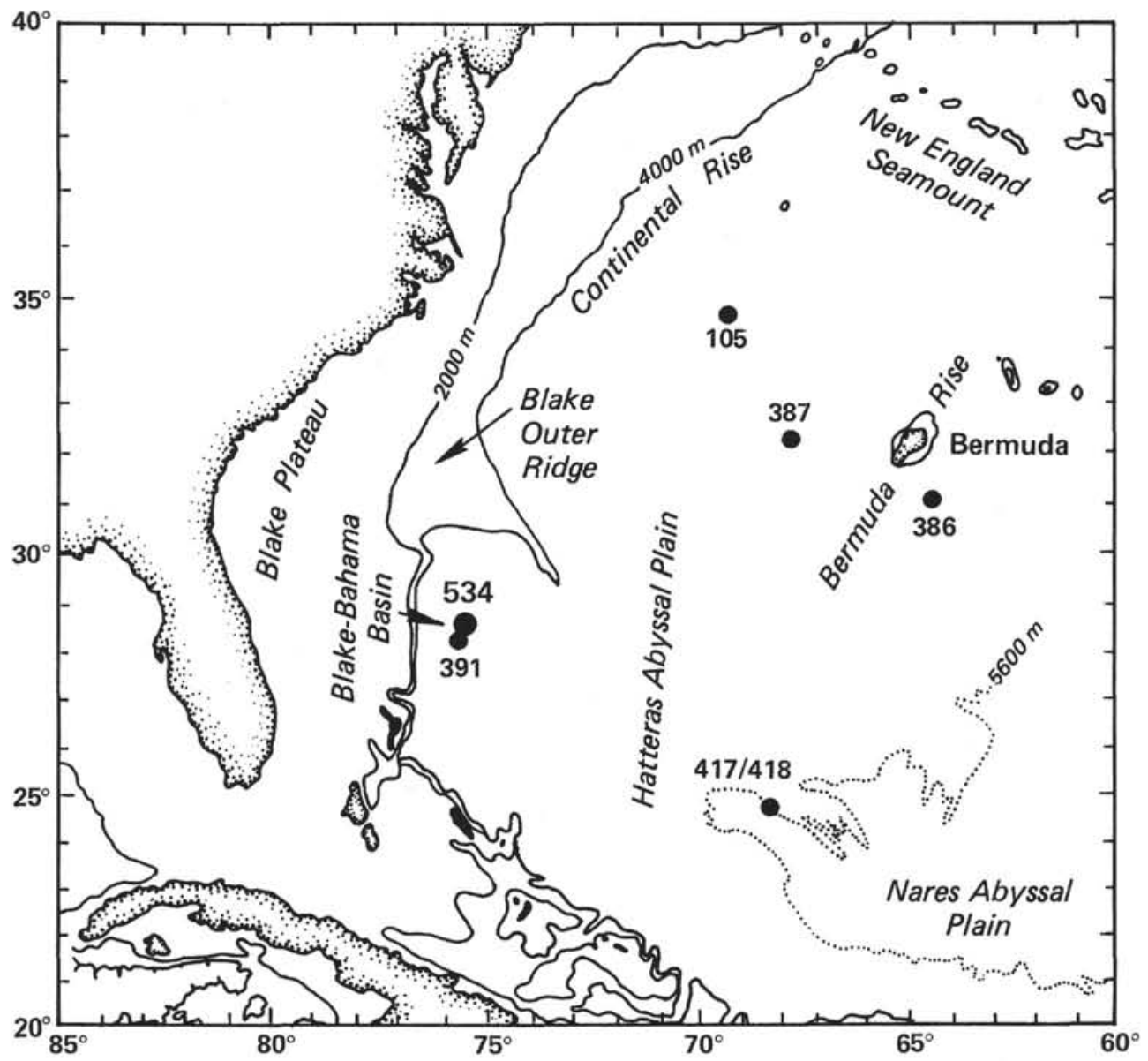

Figure 1. Location of DSDP Site 534 and of other sites mentioned in text.

Table 1. Characteristic lithologies and organic geochemical character of Site 534 Mesozoic section-based on shipboard reports.

\begin{tabular}{|c|c|c|c|c|c|c|c|}
\hline \multirow[b]{2}{*}{ Formation } & \multirow[b]{2}{*}{ Subunit } & \multirow{2}{*}{$\begin{array}{l}\text { Sub-bottom } \\
\text { depth } \\
\text { (m) }\end{array}$} & \multirow[b]{2}{*}{$\mathrm{Age}^{\mathrm{a}}$} & \multirow[b]{2}{*}{ Lithology } & \multirow[b]{2}{*}{$\begin{array}{l}\text { Max. TOC } \\
(\%)\end{array}$} & \multicolumn{2}{|c|}{ Pyrolysis } \\
\hline & & & & & & $\begin{array}{l}\text { Hydrogen } \\
\text { index }\end{array}$ & $\begin{array}{l}\text { Organic } \\
\text { type }\end{array}$ \\
\hline Plantagenet & $4 \mathrm{a}$ & $741-764$ & MA & $\begin{array}{l}\text { Red-brown variegated } \\
\text { claystone }\end{array}$ & $\begin{array}{l}0.7^{\mathrm{b}} \\
(0.2)\end{array}$ & 110 & III \\
\hline \multirow[t]{3}{*}{ Hatteras } & $4 b$ & $704-887$ & $\mathrm{AL}-\mathrm{CE}$ & $\begin{array}{l}\text { Black carbonaceous } \\
\text { claystone with green } \\
\text { interbeds }\end{array}$ & $\begin{array}{l}4.0^{\mathrm{b}} \\
(2.7)\end{array}$ & 157 & $\begin{array}{l}\text { upper III } \\
\text { lower II-III }\end{array}$ \\
\hline & $4 \mathrm{c}$ & $887-914$ & AP & $\begin{array}{l}\text { Red-brown variegated } \\
\text { claystone }\end{array}$ & $\begin{array}{l}1.8^{\mathrm{b}} \\
(0.5)\end{array}$ & 125 & III \\
\hline & $4 d$ & $914-950$ & $\mathrm{BA}-\mathrm{AP}$ & Carbonaceous claystone & $\begin{array}{l}4.6^{\mathrm{b}} \\
(2.8)\end{array}$ & 200 & II-III \\
\hline \multirow[t]{4}{*}{ Blake-Bahama } & $5 a$ & $950-1098$ & HA-BA & $\begin{array}{l}\text { Carbonaceous claystone } \\
\text { Laminated chalk }\end{array}$ & $\begin{array}{l}4.0^{\mathrm{b}} \\
(2.3)\end{array}$ & 160 & II-III \\
\hline & $5 b$ & $1107-1202$ & VA & $\begin{array}{l}\text { Laminated chalk and } \\
\text { claystone }\end{array}$ & (2.8) & 100 & III \\
\hline & $5 \mathrm{c}$ & $1202-1268$ & BE-VA & $\begin{array}{l}\text { Laminated chalk and } \\
\text { claystone }\end{array}$ & $(0.9)$ & ND & ND \\
\hline & $5 d$ & $1268-1342$ & $\mathrm{BE}$ & $\begin{array}{l}\text { Nonlaminated chalk } \\
\text { and claystone }\end{array}$ & $(0.6)$ & ND & ND \\
\hline \multirow{2}{*}{ Cat Gap } & $6 \mathrm{a}$ & $1342-1428$ & TI-BE & Claystone and limestone & (3.1) & ND & ND \\
\hline & $6 \mathrm{~b}$ & $1428-1496$ & $\mathrm{OX}-\mathrm{TI}$ & Claystone and limestone & $(0.3)$ & ND & ND \\
\hline \multirow[t]{3}{*}{ Unnamed } & $7 \mathrm{a}$ & $1496-1549$ & ox & Variegated claystone & (3.9) & ND & ND \\
\hline & $7 \mathrm{~b}$ & $1549-1617$ & $\mathrm{CA}-\mathrm{OX}$ & Limestone and claystone & $1.5 \mathrm{~b}$ & 7 & Residual \\
\hline & $7 \mathrm{c}$ & $1617-1635$ & $\mathrm{CA}$ & $\begin{array}{l}\text { Green black and brown } \\
\text { claystone }\end{array}$ & $(2,8)$ & 50 & III \\
\hline
\end{tabular}

${ }^{\mathrm{a}} \mathrm{MA}=$ Maestrichtian; $\mathrm{CE}=$ Cenomanian; $\mathrm{AL}=\mathrm{Albian} ; \mathrm{AP}=$ Aptian; $\mathrm{BA}=$ Barremian, $\mathrm{HA}=$ Hautervian; $\mathrm{VA}=$ Valanginian; $\mathrm{BE}=$ Berriasian; $\mathrm{TI}=$ Tithonian; $\mathrm{KI}=$ Kimmeridgian; $\mathrm{OX}=$ Oxfordian; $\mathrm{CA}=$ Callovian.

b From shipboard organic geochemistry reports: other TOC data, in parentheses, are from Appendix I (this volume).

c Average hydrogen index calculated from shipboard data presented in the Site 534 report, this volume. Organic type estimated by evaluating average hydrogen indices against our Figure 2. ND $=$ not determined. 
Table 2. Percent TOC, elemental ratios $(\mathrm{H} / \mathrm{C}$ and $\mathrm{O} / \mathrm{C})$, pyrolysis data, and organic matter types.

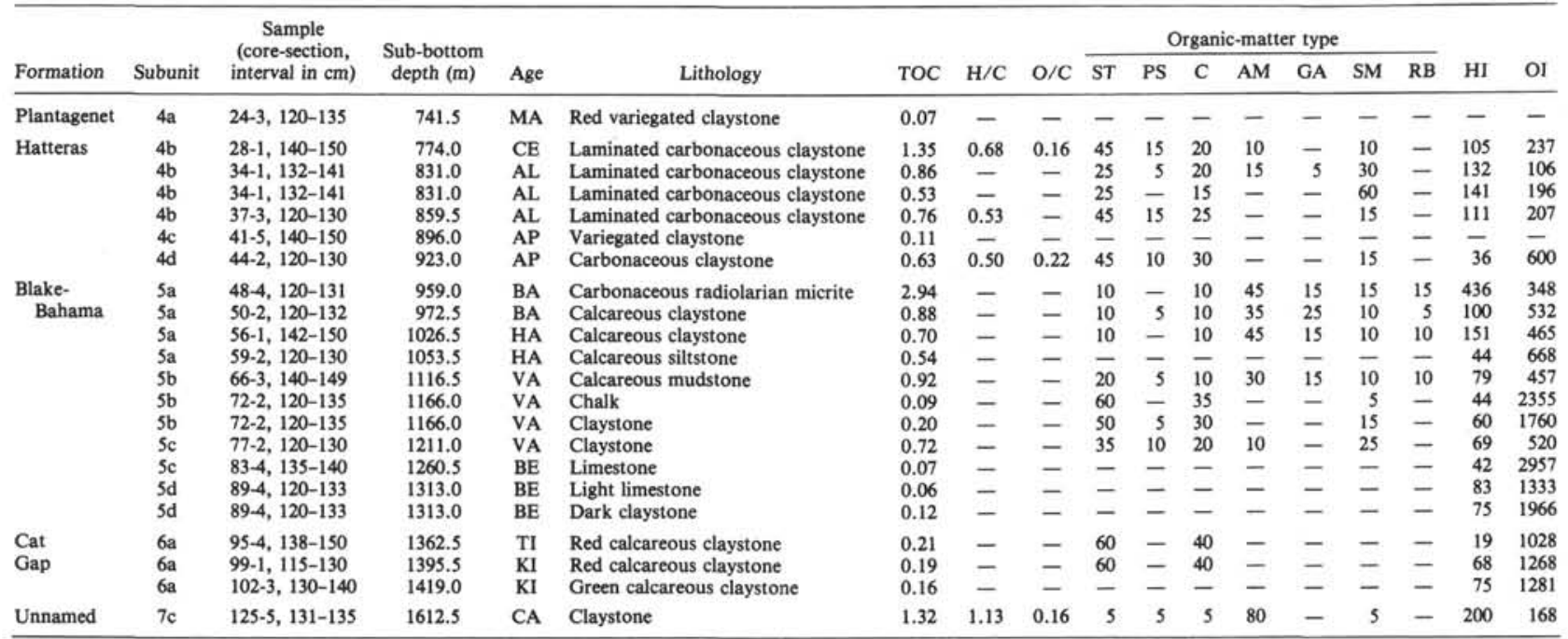

Note: Elemental analyses of extracted organic matter by Robertson Research (US) Inc.; TOC by LECO at Exxon Production Research Co. Organic-matter types by T. C. Masran (in percent of kerogen fraction) using organic matter classification scheme of Masran and Pocock (1981). ST = structured terrestrial, PS $=$ pollen and spores, C $=$ charcoal; AM $=$ amorphous; $\mathrm{GA}=$ gray amorphous; $\mathrm{SM}=$ structured marine, $\mathrm{RB}=$ amorphous round bodies. Formations = Plantaganet, Hatteras, Blake-Bahama, Cat Gap, and Callovian unnamed. For age abbreviations see Table 1 . $\mathrm{HI}=$ hydrogen index (mg hydrocarbons $/ \mathrm{g}$ TOC), OI = oxygen index (mg CO $2 / \mathrm{g}$ TOC), by Rock-Eval pyrolysis. - indicates no available data,

sive, in that we analyzed only pieces of the cores frozen for organic geochemical work. We analyzed these samples by LECO for total organic carbon (TOC), by pyrolysis for hydrogen index and oxygen index, and visually for different types of organic matter; some samples were analyzed elementally for the $\mathrm{C}, \mathrm{H}$, and $\mathrm{O}$ contents of kerogen extracts (Table 2).

\section{Plantagenet Formation}

The brownish colored claystone of Subunit 4a contains very little organic matter (Tables 1 and 2). Shipboard analysis by pyrolysis shows that the organic matter from this unit has a low hydrogen index typical of kerogen classified as Type III and probably having a terrestrial source (Table 1, Fig. 2; and Site 534 report, this volume). There was too little particulate organic matter in our sample to permit detailed analysis of kerogen type. The red brown coloration and lack of organic matter suggest deposition under oxidizing conditions (Site 534 report, this volume).

\section{Hatteras Formation}

The Hatteras Formation is characterized by abundant carbonaceous claystone and scarcity of carbonate (Table 1; and Site 534 report, this volume). This formation contains the main "black shale" units of the North
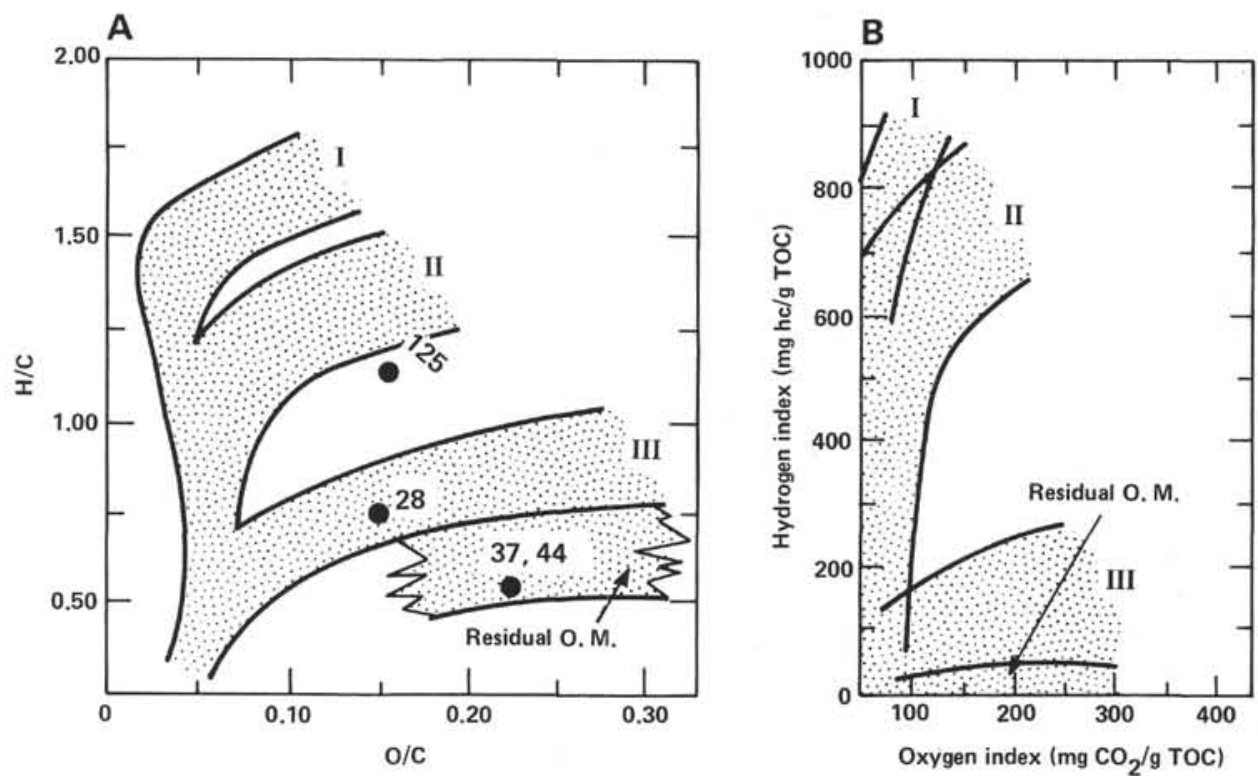

Figure 2. Characterization of organic matter (O.M.) into four main types (I-III and residual) by A. elemental analysis and B. pyrolysis, based on Tissot et al. (1980). 
Atlantic. Sheridan, Gradstein, et al., (Site 534 report, this volume) divide it into three parts (Subunits $4 \mathrm{~b}, 4 \mathrm{c}$, and 4d) based on lithology (Table 1). All of the subunits are claystones, because deposition took place in deep water at a time when the carbonate compensation depth (CCD) was high in the water column (Thierstein, 1979).

Subunits $4 \mathrm{~b}$ and $4 \mathrm{~d}$ are characterized, as is much of the mid-Cretaceous "black shale" of the deep North Atlantic, by alternating interbeds of black carbonaceous claystone relatively rich in organic matter and greenish claystone poor in organic matter (Site 534 report, this volume). The contrast between these adjacent layers can be seen from Table 2 (Core 34, Section 1): the black layer contains about twice as much organic matter as the green one. DSDP data files show that in these units TOC fluctuates from 0.1 to $2.8 \%$, and we calculate from those data that the average TOC of the rich units (with more than $1 \%$ TOC) is $1.7 \%$. Shipboard data show that TOCs reach 4.0 to $4.6 \%$ in these two units (Table 1) (Site 534 report, this volume). Our richest sample contained $1.35 \%$ TOC (Table 2-Core 28, Section 1); that of Herbin et al. (this volume) had $2.6 \%$ TOC.

Most of the carbonaceous layers are finely laminated, whereas many of the intervening green ones are bioturbated (Site 534 report, this volume). This change in sedimentary structure is taken to reflect changes in the degree of oxygenation of the depositional environment, the laminations representing periods when bottom waters were so low in oxygen as to prevent much benthic faunal activity (we will refer to these conditions as reducing).

Oxidizing conditions prevailed throughout the deposition of Subunit $4 c$, which is a red brown, variegated, and bioturbated claystone containing very little organic matter (Tables 1 and 2; and Site 534 report, this volume).

Our five samples from the carbonaceous units of the Hatteras Formation (Subunits $4 \mathrm{~b}$ and $4 \mathrm{~d}$ ) contain an organic facies dominated by terrestrially derived material (including charcoal), with subordinate amounts of structured marine organic matter and almost no amorphous material (Table 2). One sample in Core 34, Section 1 has a dominantly marine organic facies. The average organic facies for the five samples is $37 \%$ structured terrestrial organic matter, $9 \%$ pollen and spores, $22 \%$ charcoal, $6 \%$ amorphous, and $26 \%$ structured marine organic matter. There was too little organic matter present for us to be able to characterize the organic facies of the variegated claystone (Subunit $4 \mathrm{c}$ ).

Organic matter may also be characterized by elemental analysis and by pyrolysis into four main types of organic matter, as shown in Figure 2. Shipboard pyrolysis measurements (Site 534 report, this volume) show a downhole increase in the hydrogen index of kerogen from Subunits $4 \mathrm{~b}$ to $4 \mathrm{~d}$, interrupted by a zone of low hydrogen index corresponding to Subunit 4c (Table 1). The hydrogen indices tend to follow the TOC (Table 1), as seen at other nearby sites in the western North Atlantic (Fig. 3). This pattern is interpreted as showing that the TOC increases in proportion to the preservation of labile, hydrogen-rich components, most of which are

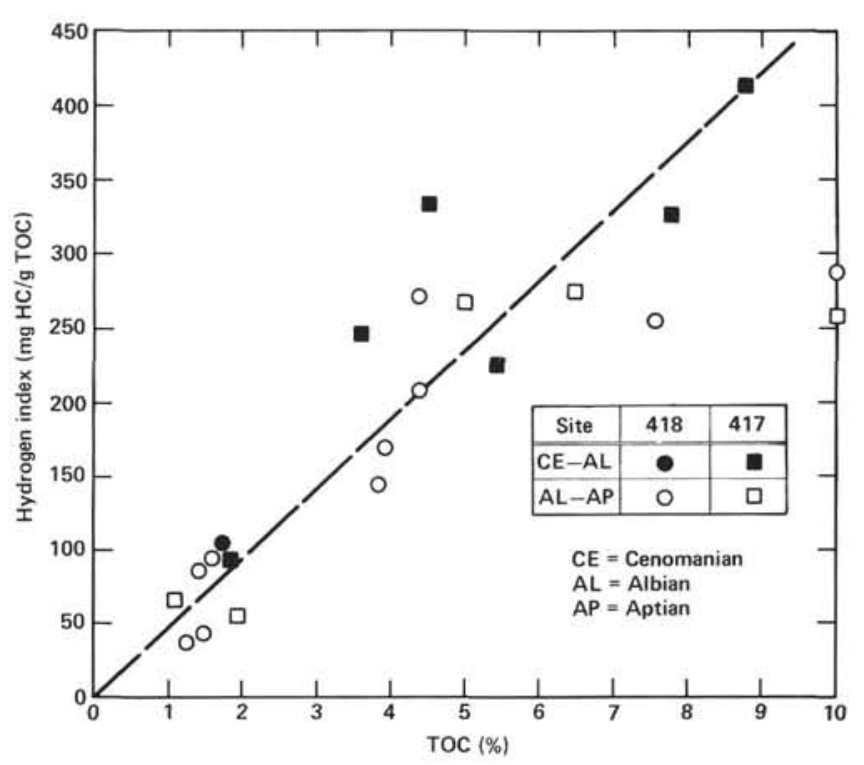

Figure 3. Dependence of TOC on preservation of hydrogen-rich organic matter. (Based on data from Deroo et al. [1980]. See Fig. 2 for limits to organic matter Types II and III.)

amorphous. Although we do not see a well-defined relationship between TOC and amorphous content at Site 534 (Table 2), such a relationship is characteristic of both the eastern and western North Atlantic Cretaceous black shales (Summerhayes, 1981).

Consideration of the average hydrogen index alone (Table 1) gives the impression that the organic matter of Subunits $4 \mathrm{~b}$ and $4 \mathrm{~d}$ belongs to Type III, which is usually thought of as terrestrially derived (Fig. 2). Actually, although many samples do belong to Type III, some belong to the residual category (of Fig. 2) and consist of highly refractory material-probably charcoal (e.g., Core 44, Section 2-Table 2), whereas others belong to Type II and are probably derived mainly from marine organic matter (Site 534 report, this volume). Thus we are dealing with a mixed marine-terrestrial organic facies that is dominated by terrestrial-plant remains mixed with charcoal. The downhole increase in average hydrogen index from Subunits $4 \mathrm{~b}$ to $4 \mathrm{~d}$ (Table 1) probably reflects an increasing admixture of marine material in the older samples. This increasing admixture goes along with an increase in the "marine" character of the clay mineral assemblage (Site 534 report, this volume). Herbin et al. (this volume) agree that Subunit $4 \mathrm{~b}$ has low hydrogen indices, and they show from gas chromatography that the organic extract is highly terrestrial in character. Our pyrolysis data confirm the Type-III or residual character of the organic matter of the Hatteras Formation (Table 2). The association of a marine organic facies with a low hydrogen index in Core 34, Section 1 (green sediment with low TOC, probably deposited under oxidizing conditions) suggests that not all Type-III organic matter is necessarily terrestrial. It may be biologically degraded marine organic matter that has lost its hydrocarbon-generating potential. We would not expect to see this degradation in samples that were deposited under reducing conditions. 
These findings confirm earlier reports that the organic facies of the mid-Cretaceous "black shales" in the western North Atlantic is dominated by terrestrial organic matter (Tissot et al., 1980; Summerhayes, 1981). At some other western North Atlantic DSDP sites (e.g., Site 105), parts of the Cenomanian are unusually rich in marine organic matter (Tucholke and Vogt, 1979; Summerhayes, 1981). Sheridan, Gradstein, et al. (Site 534 report, this volume) thought that they could see some evidence for this Cenomanian "abundance spike" at Site 534, but we could find no evidence for either TOC enrichment or concentrations of marine organic matter in Cenomanian samples at Site 534; the maximum TOC value for the Cenomanian samples analyzed by DSDP is $2 \%$, and the pyrolysis data indicate Type-III organic matter. If the richly marine Cenomanian interval was deposited at this site, it may have been eroded.

\section{Blake-Bahama Formation}

This formation is highly calcareous, dominated by chalks and interbedded calcareous claystones, some of which are carbonaceous. The most carbonaceous beds occur toward the top of Subunit 5a, which is transitional to the Hatteras Formation (Table 1; and Site 534 report, this volume). Much of the Blake-Bahama Formation is turbiditic, implying the lateral introduction of organic matter. Deposition took place at a time when the CCD was much deeper than it was in the Barremian-Cenomanian (Thierstein, 1979; Site 534 report, this volume). Many of the chalks and claystones are laminated, especially in Subunits $5 \mathrm{a}, 5 \mathrm{~b}$, and $5 \mathrm{c}$, suggesting that bottom waters were poorly oxygenated; Subunit $5 \mathrm{~d}$ is not laminated, suggesting that bottom waters were oxidizing at the beginning of the Early Cretaceous (Site 534 report, this volume).

The calcareous claystones tend to have more organic matter than the chalks, as seen, for instance, in Core 72, Section 2 and Core 89, Section 4 (Table 2). As mentioned above, the upper part of Subunit 5a has the most organic matter. Subunit $5 \mathrm{~b}$ is also enriched in organic matter, Subunit $5 \mathrm{c}$ is less so, and Subunit $5 \mathrm{~d}$ not at all, as shown also by Herbin et al. (this volume). Background TOCs are about $0.1 \%$ (Table 2; Site 534 report and Appendix I, this volume), values typical of pelagic deep-sea sediments (McIver, 1975).

Analyses of organic matter type show that there are two organic facies within the Blake-Bahama Formation (Table 2). One, in samples with more than $0.5 \%$ TOC, is dominated by amorphous organic matter: it averages $55 \%$ amorphous material, $12 \%$ structured marine material, $17 \%$ structured terrestrial material, $4 \%$ pollen and spores, and $12 \%$ charcoal. The other, in samples with less than $0.5 \% \mathrm{TOC}$, is much richer in refractory components, averaging $55 \%$ structured terrestrial material, $2.5 \%$ pollen and spores, $32.5 \%$ charcoal, and $10 \%$ structured marine material. This facies change is characteristic of the Early and mid-Cretaceous sediments of the deep western North Atlantic (Summerhayes, 1981). It is attributed to decomposition of labile amorphous and marine organic matter during periods when bottom waters were oxidizing, and preservation of those materials when bottom waters were reducing.

Pyrolysis data show that the bulk of the organic matter belongs to Type III (Tables 1 and 2, and Fig. 2); inspection of Table 2 suggests that degraded marine material contributed to the terrestrial organic matter providing the low hydrogen index. Some samples have high hydrogen indices, belong to Type II, and probably contain mainly marine-derived organic matter (Site 534 report, this volume), especially in Subunit 5a (Core 48, Section 4, Table 2). Herbin et al. (this volume) recorded hydrogen indices up to 263 in Subunit $5 \mathrm{a}$, up to about 150 in Subunit $5 \mathrm{~b}$, and 0 in Subunit $5 \mathrm{~d}$ (Subunit $5 \mathrm{c}$ was not analyzed). Our data confirm that low hydrogen indices characterize Subunits 5b, 5c, and 5d (Table 2). From the low average hydrogen index (Tables 1 and 2) and the moderately high amorphous content (Table 2), we deduce that some of the amorphous material in these samples may be derived from terrestrial plant remains or is very highly degraded marine organic matter. Much the same conclusion was reached by Summerhayes (1981) and Masran (personal communication, 1978) about the amorphous organic matter in pre-Cenomanian Early and mid-Cretaceous sediments from elsewhere in the deep western North Atlantic. Gas chromatography on samples from Subunit 5b supports a predominantly terrestrial source for the organic matter (Herbin et al., this volume).

\section{Cat Gap Formation}

These Jurassic sediments are pinkish limestones and greenish gray calcareous claystones that generally are neither laminated nor bioturbated (Table 1; and Site 534 report, this volume). Local accumulations of carbonaceous claystone suggest that bottom waters were anoxic at times (e.g., in Cores 99-101, where TOCs reach a maximum of $3.1 \%$-Table 1 , and Site 534 report, this volume). Most of the sediments in the Cat Gap Formation contain 0.1 to $0.3 \%$ TOC (Site 534 report, this volume; Herbin et al., this volume; and Tables 1 and 2), like typical pelagic sediments (McIver, 1975). Organic matter types are entirely refractory and terrestrial where TOCs are low (Table 2), as is typical in highly oxidizing depositional environments. Hydrogen indices are also very low (Table 2; and Herbin et al., this volume).

\section{Callovian-Oxfordian Sediments}

Most of the Callovian-Oxfordian section consists of green and brown claystone, with some grey to black carbonaceous "black shale" beds (Site 534 report, this volume). The organic-rich beds are set in a "background" of organic-poor green claystones, or marly limestones. Limestone abundance decreases with depth as "black shale" abundance increases until, in Core 125, "black shale" makes up half of the core.

The carbonaceous beds, like that in Core 125, are laminated and contain glauconite, phosphorite, fishbones, and unusual benthic foraminiferal faunas, suggesting deposition in poorly oxygenated bottom waters (Site 534 report, this volume). TOCs reach $2.8 \%$ in Core 
125 (Subunit 7c), but there is also organic-rich sediment in Subunit $7 \mathrm{a}$, where TOCs reach $3.1 \%$ (Table 1 ). Herbin et al. (this volume) report TOCs as high as $3.1 \%$ in Subunit 7c, Core 126. The "background" sediments mostly contain 0.1 to $0.3 \%$ TOC, increasing in Subunit $7 \mathrm{c}$ to about $0.6 \%$; in contrast, shipboard analyses suggest that "background" TOCs in Subunit 7c may be about $1.3 \%$. Our analyses of a frozen sample from Core 125 gave a TOC of $1.32 \%$ (Table 2); Herbin et al. (this volume) report $1.8 \%$ TOC in this core.

The organic facies of the sample that we analyzed (Core 125, Section 5) is dominantly amorphous with subordinate terrestrial material and a little structured marine organic matter (Table 2). Shipboard pyrolysis data suggest that organic-rich sediments in this same core have hydrogen indices around 50, which is either low Type III or residual organic matter (see Fig. 2). Our elemental analyses suggest, in contrast, that the amorphous material in Core 125 is marine-derived (Table 2, Fig. 2). Our pyrolysis data put this sample on the border between Types II and III, suggesting that it is a mixture of marine and terrestrial organic matter (Table 2, Fig. 2). Herbin et al. (this volume) show that the TOC-rich samples have the higher hydrogen indices, which reach 221 in Core 26, and 161 in Core 125, indicating an admixture of terrestrial and aquatic organic material. We conclude that the organic matter in these mid-Jurassic sediments is most probably dominantly terrestrial with some marine admixture becoming important where TOCs are high.

\section{DISCUSSION}

In the foregoing section we have confirmed that at Site 534 organic matter is concentrated in the mid-Cretaceous, is present in lesser amounts in the Early Cretaceous, occurs in some organic-rich beds in the Jurassic, and is not abundant in the Late Cretaceous. Most of the organic matter is terrestrially derived. Marine organic matter is not commonly abundant.

Our other objectives were to establish the controls of deposition of organic matter at this site, and to relate our findings to the history of deposition of organic matter in the Mesozoic of the western North Atlantic in order to enable us to draw inferences about the circulation of the basin and the climate of those times.

\section{Distribution of Organic Matter through Time}

In the Cretaceous sediments of the western North Atlantic there is a gradual increase in TOC enrichment from the Berriasian to the Cenomanian. Maximum TOCs are 1 to $3 \%$ in the Earliest Cretaceous (Berriasian to Valanginian); rise to 3 to $5 \%$ in the Hauterivian-Barremian-Aptian-Albian; and reach $10 \%$ or more in the Cenomanian-Turonian (Thierstein, 1979, Fig. 12). There is a somewhat similar picture in the eastern North Atlantic (Thierstein, 1979, Fig. 13).

These changes in TOC with time may reflect changes in the rates of sedimentation of lithogenous or carbonate components, as well as changes in the rate of supply or rate of preservation of organic matter. In particular, the enrichment of Barremian-Aptian sediments in TOC could have been caused in part by the abrupt raising of the CCD from $5 \mathrm{~km}$ to $3 \mathrm{~km}$ at the Barremian/Aptian boundary (Thierstein, 1979). This event, which delineates the boundary between the calcareous Blake-Bahama Formation and the siliceous Hatteras Formation (Site 534 report, this volume), can be seen in Figure $4 \mathrm{~A}$ as a sharp drop in the rate of accumulation of carbonate between Subunits 5a and 4d. Clearly, carbonate deposition must have obscured the TOC accumulation picture by dilution in the Valanginian through the Barremian (Subunits 5c-5a-Fig. 4A).

The pattern of peak and background rates of accumulation of TOC at Site 534 is one of a steady increase from the Valanginian through the Barremian (Subunits 5c through 4d) (Fig. 4B and 4C). As explained in the caption to Figure 4, peak values represent accumulation under reducing conditions, whereas background values represent accumulation under oxidizing conditions. Both the peak and background rates of TOC accumulation drop in the Aptian (Subunit 4c), when the ocean was predominantly oxidizing, and rise again in the Albian-Cenomanian (Subunit 4d), when conditions were, again, predominantly reducing, with temporary intervals of oxidation (Fig. 4B, 4C).

Although the accumulation of TOC is independent of the accumulation of carbonate, it does show an inverse relation to the accumulation of lithogenous clastic components (Figs. 4 and 5). At times when rates of clastic input were highest (Subunits $4 c, 5 c$ ), rates of accumulation of organic matter were lowest, and vice versa. This inverse relationship is not caused by dilution of organic matter by clastic input. Instead, it means that these two independent variables are responding in opposite ways to some outside force-in this case most probably a change in sea level. As sea level rises, clastic input wanes and either productivity increases or the rate of preservation of organic matter increases. Because all sediments are laminated (except in Subunit $4 c$ ) and because the rate of TOC accumulation changed, not only under reducing conditions (peak values, Fig. 4B) but also under oxidizing conditions (background values, Fig. 4C), it seems unlikely that there was a change in rate of preservation with time. A change in productivity with time seems more probable: it would have required a change in the rate of supply of nutrients to the surface waters. We show later on in this report what may have caused this rate to change.

By removing the carbonate component (calculating TOCs on a carbonate-free basis) we can improve our view of the change in TOC with time in the western North Atlantic. At DSDP Sites 105, 387, 391, and 534 there is a steady increase in maximum carbonate-free TOC values from the Berriasian through the Valanginian towards the Hauterivian (Fig. 6). Barremian sediments have high TOC maxima, but there is a pronounced drop in TOC at all of these sites in the Aptian-Albian (Fig. 6); this drop can also be seen at Site 417 (Fig. 6; and Hochuli and Kelts, 1980). At Site 534, this event is marked by deposition of red brown variegated clays under predominantly oxidizing conditions (Subunit 4c; Table 1). TOCs are high again in the Ceno- 

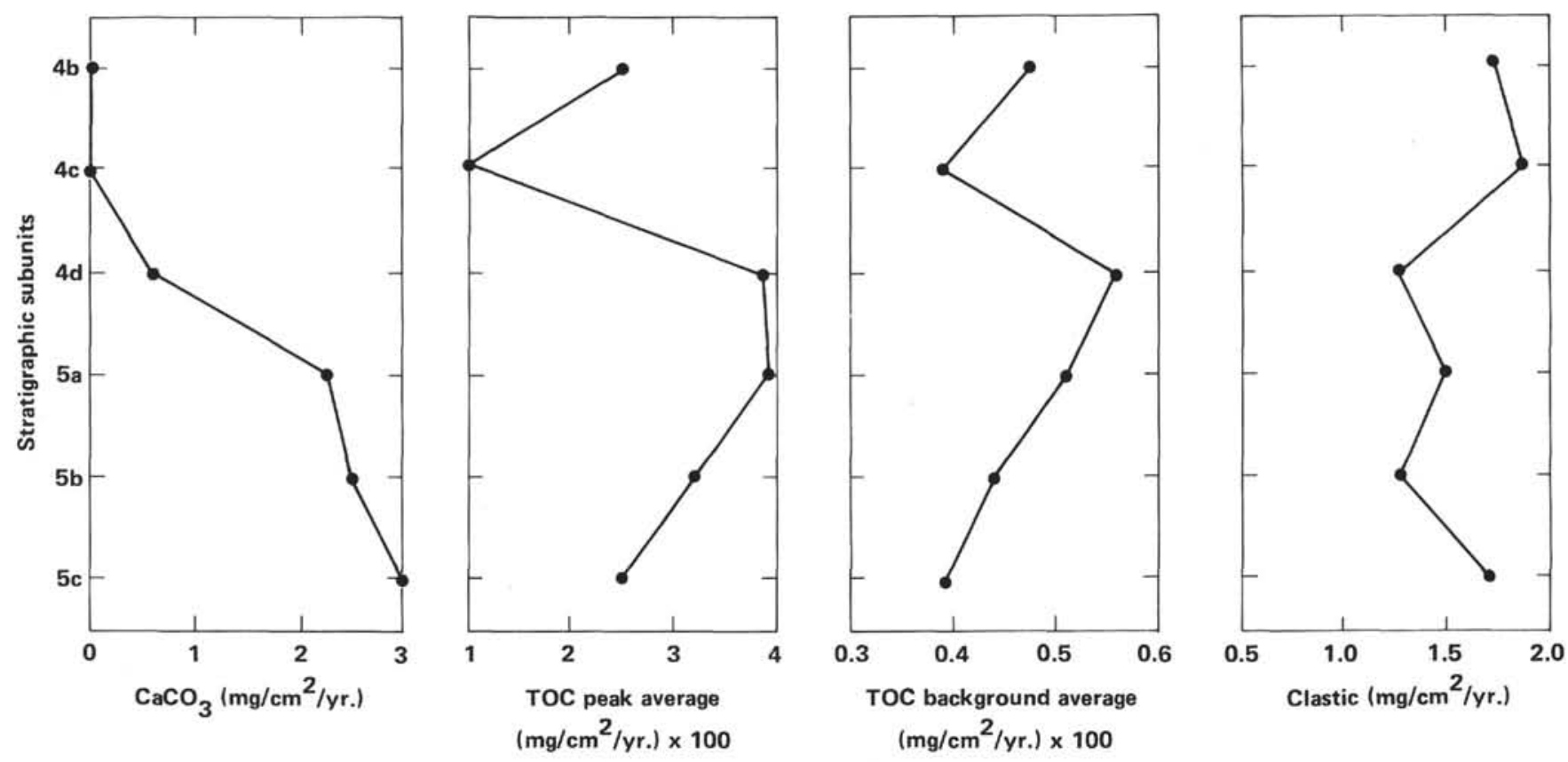

Figure 4. Rates of accumulation of carbonate, organic matter, and lithogenous clastic materials. (Calculated by using sedimentation rates of $10 \mathrm{~m} / \mathrm{m} . \mathrm{y}$. for Unit 4 [Subunits $4 \mathrm{~b}-\mathrm{d}$ ], and $21 \mathrm{~m} / \mathrm{m} . \mathrm{y}$. for Unit 5 [Subunits 5a-c] [Site 534 report, this volume], an average porosity of $30 \%$, and an average density of $2.65 \mathrm{~g} / \mathrm{cm}^{3}$. These give bulk accumulation rates of $1.86 \mathrm{mg} / \mathrm{cm}^{2} / \mathrm{yr}$. for Unit 4 , and $3.9 \mathrm{mg} / \mathrm{cm}^{2} / \mathrm{yr}$. for Unit 5 . TOC and carbonate data were averaged for each subunit; noncarbonate data include some biogenic opal. TOC accumulation rates are bimodally distributed, with one population above $1 \mathrm{mg} / \mathrm{cm}^{2} / \mathrm{yr} . \times 100$, and another below that value. All of the smaller values were averaged to produce a "background" TOC accumulation rate; the larger values were averaged to produce a "peak" TOC accumulation rate. Peak values represent deposition under reducing conditions; background values represent deposition under oxidizing conditions.)

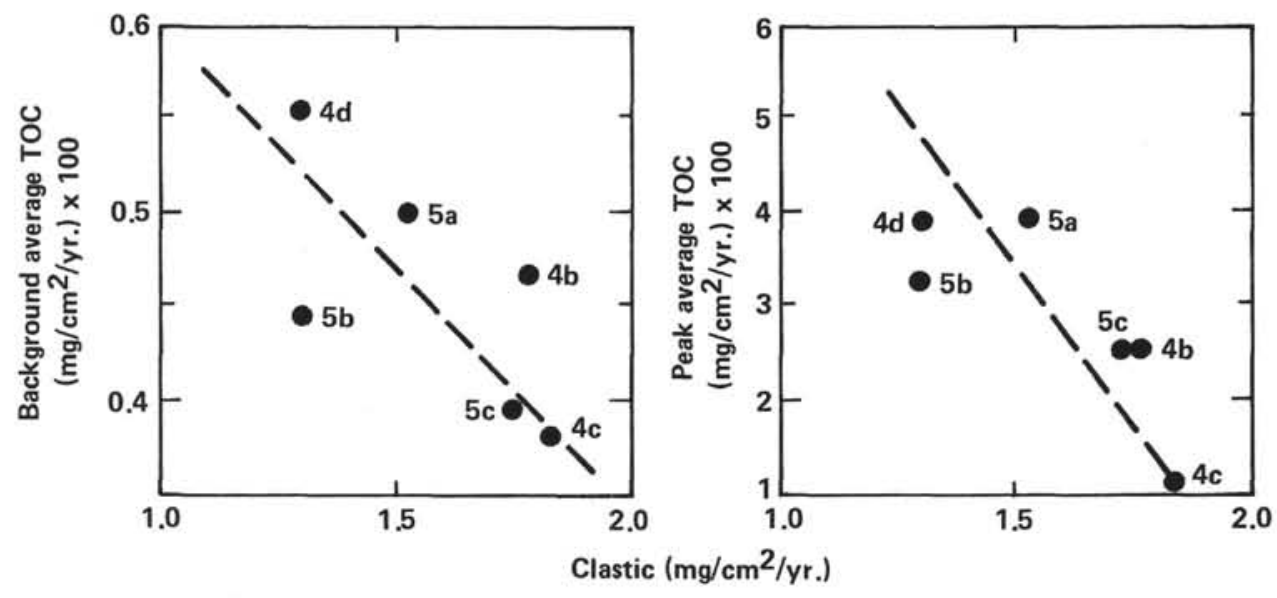

Figure 5. Interdependence of rates of accumulation of organic and lithogenous components (based on data from Fig. 4).

manian at Sites $105,386,387$, and 417 , but not at Sites 391 or 534 (perhaps because of erosion?) (Fig. 6).

\section{Relation of TOC to Changes in Sea Level}

As implied earlier, the TOC pattern of the midCretaceous may be linked to changes in sea level (Summerhayes, 1981; Scholle and Arthur, 1980). Vail et al. (1977) show that the sea level was high through the Latest Jurassic and into the Berriasian, dropped at the end of Berriasian times, then rose to a peak in the Cenomanian, with a major interrruption in the late Aptian (Fig. 7). The two major sea-level lows (Valanginian, corresponding to Subunit 5c, and Aptian, corresponding to Subunit 4c) are the times of highest rates of clastic sedimentation and lowest rates of accumulation of organic matter (Figs. 4 and 7).

There is also a close relation between sea-level change and the oxidation of bottom water in the mid-Cretaceous North Atlantic. Sediments first became commonly laminated in the Valanginian (Subunit 5c) (Site 534 report, this volume) as sea level was rising (Fig. 7). We assume that the North Atlantic must have been well stratified at this time, with predominantly reducing bottom waters, a state that continued into the Aptian. 

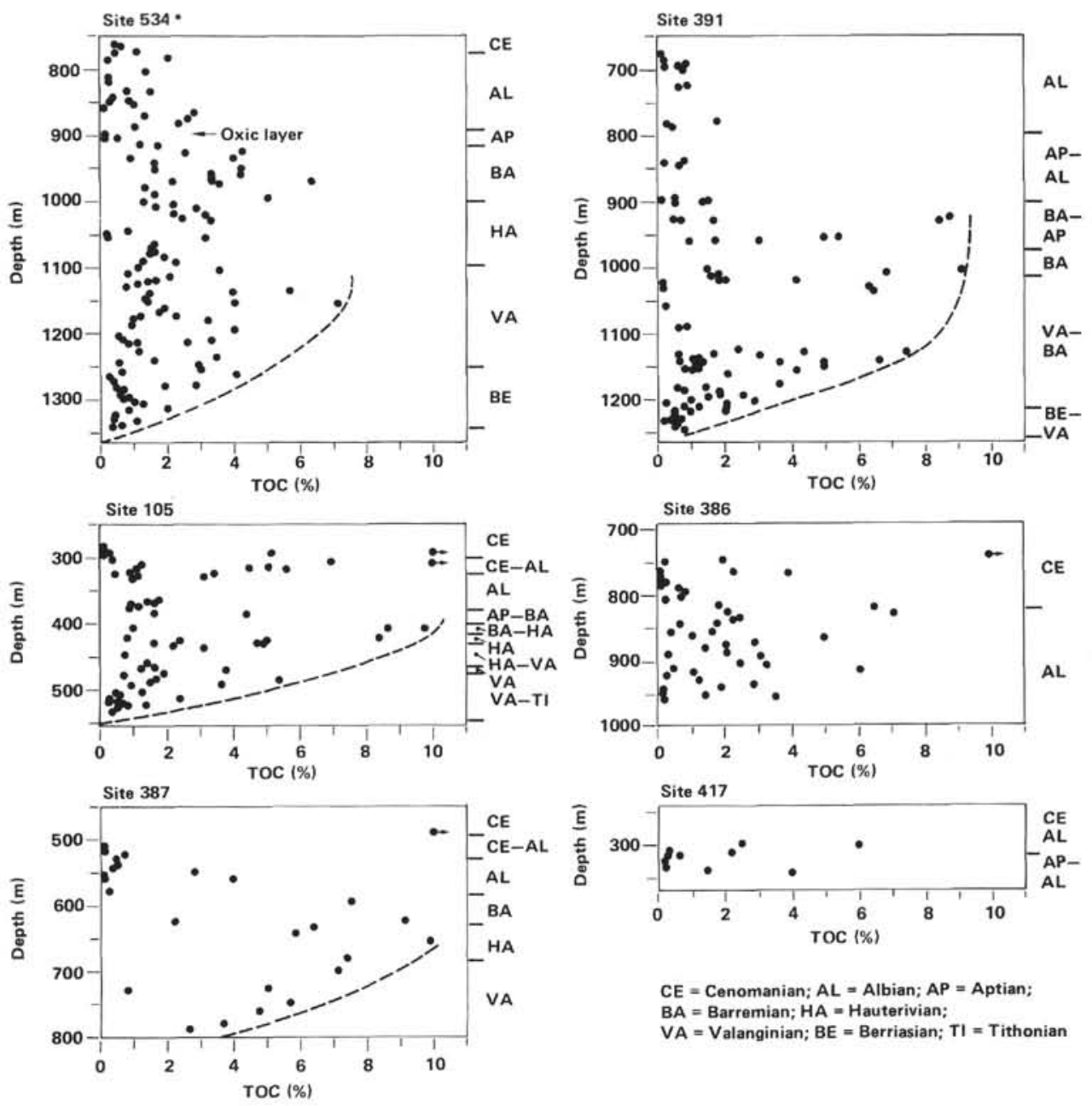

Figure 6. Downhole distribution of carbonate-free TOC at DSDP sites. (Calculated from data given in appropriate DSDP site reports and Appendix I; data from Site 534 excludes two analytically oddball values in Core 78, Section 4 and Core 79, Section 4.)

Short-term, periodic interruptions, probably climatically induced and recurring at intervals of 10 to $50,000 \mathrm{yr}$., made the bottom waters temporarily oxidizing (Arthur and Natland, 1979). When the bottom waters were oxidizing, organic matter was consumed by benthic organisms, reducing TOCs to "background" levels of less than $1 \%$ (Fig. 6).

The late Aptian sea-level drop (Fig. 7) is associated with widespread oxidation that persisted for a few million years and gave rise to the red brown sediments of Subunit $4 \mathrm{c}$ at Site 534 (Figs. 4 and 6). Subsequently, as the sea level rose (Fig. 7), conditions became again predominantly reducing, enabling organic matter to accumulate in substantial amounts (Figs. 4 and 6). The oxidation event is seen in the TOC record at several of the western North Atlantic sites (Fig. 6), as mentioned earlier.

It is significant that the pattern of TOC accumulation is not simply one of constant flux diluted by clastic input. Oxidation affects accumulation, especially in diminishing the TOC flux in the Aptian (Subunit $4 \mathrm{c}-$ Fig. 4C, 4B). Also, as mentioned earlier, the gradual increase in both peak and background rates of accumula- tion of TOC through time (Subunits $5 \mathrm{c}$ to $4 \mathrm{~d}-$ Fig. $4 \mathrm{C}$, 4B) suggests that the North Atlantic became gradually more productive as the sea level rose in the Valanginian through the Aptian.

\section{Distribution of Organic Facies}

The proportions of marine and terrestrial organic matter changed with time during the Cretaceous. For instance, at Site 534, in samples with more than $0.5 \%$ TOC, there is more terrestrial organic matter in Subunits $4 \mathrm{~b}, 4 \mathrm{c}$, and $5 \mathrm{~b}$, representing times of low or rising sea level, than in Subunits 4d and 5a, when sea level was high (compare Tables 1 and 2 with Fig. 7). This change goes along with a change in clay mineralogy (Site 534 report, this volume). If we assume that the flux of terrestrial organic matter to the sediment parallels that of clastics (Fig. 4D), then it is evident that much of the low TOC flux at times of high clastic rates of accumulation should be terrestrial (Fig. 4B, 4C), and that the flux of terrestrial material should decline along with a decline in clastic input.

The proportions of marine and terrestrial organic matter changed from one part of the North Atlantic to 


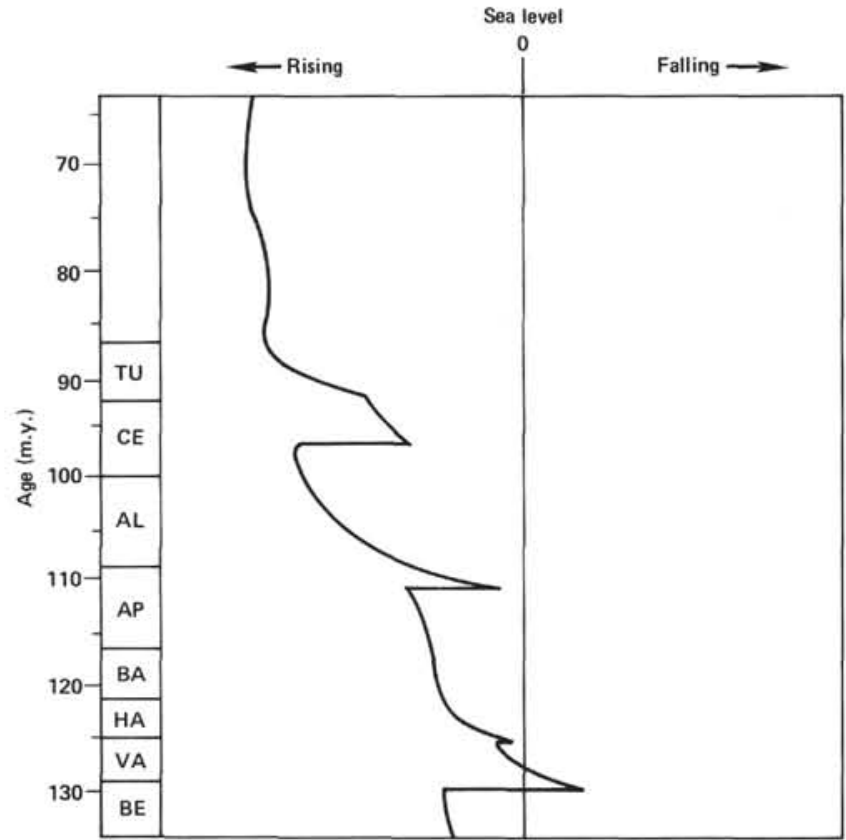

Figure 7. Relative changes of sea level in the Cretaceous (from Vail et al., 1977). (Tu = Turonian; see Fig. 6 for key to rest of Ages).

another. For example, in the western North Atlantic there is much more terrestrial organic matter than in the southeastern North Atlantic in the mid-Cretaceous. This is thought to reflect the influence of climate and circulation: the southeastern North Atlantic had an arid hinterland, low runoff, coastal upwelling, and high marine productivity, whereas the western North Atlantic had a humid climate and high runoff, lacked coastal upwelling, and had lower productivity (Tissot et al., 1980; Summerhayes, 1981).

The organic facies also changed in relation to distance from shore. For instance, in the western North Atlantic (except in the Cenomanian) we find more terrestrial organic matter nearshore (e.g., DSDP Sites 105, 391, and 534) than offshore (e.g., DSDP Sites 386, 387, 417, and 418) (Summerhayes, 1981). This difference reflects sedimentary processes, less terrigenous sediment (i.e., less terrestrial organic matter) being transported to the offshore than to the nearshore sites to dilute the marine contribution. We calculate that dilution by clastics nearshore may be five times what it is offshore. For instance, the rate of accumulation of clastics of fshore at Site 417 is about $0.3 \mathrm{mg} / \mathrm{cm}^{2} / \mathrm{yr}$, , a factor of five less than it is at Site 534 (see Fig. 4D). As a result, TOCs are much higher at Site 417 (averaging $4.7 \%$ in the AlbianCenomanian, according to data from Deroo et al., 1980) than they are at Site 534 (see Tables 1 and 2). Rates of accumulation of TOC at both sites are about the same $\left(2.2 \mathrm{mg} / \mathrm{cm}^{2} / \mathrm{yr} . \times 100\right.$ in the Albian-Cenomanian at Site $417,3.4 \mathrm{mg} / \mathrm{cm}^{2} / \mathrm{yr} . \times 100$ in the basal Aptian-Albian at Site 417, and comparable values at Site 534, as seen from Fig. 4B). The organic facies at Site 417 is correspondingly less terrestrial and more marine, on average, that at Site 534 (compare Table 1 with Fig. 3). Site 417 has more Type II-III mixtures than does Site 534. Nevertheless, the terrestrial influx is still large enough to keep the hydrogen index below pure Type-II material even at Site 417 (compare Fig. 2 with Fig. 3).

At Site 417, because individual organic-rich beds may be dominated by single dinoflagellate species, Hochuli and Kelts (1980) deduce that the source of the marine organic matter most probably was periodic plankton blooms. The terrestrial organic matter was most probably deposited both nearshore and offshore from suspension either in turbidity currents or in the slow-moving, near-bottom nepheloid layer (Summerhayes, 1981; Site 534 report, this volume). We find no evidence to support the suggestion by Montadert, Roberts, et al. (1979), and Jenkyns (1980), that the high TOCs and terrestrial character of the organic facies of the western North Atlantic result from the influx of massive amounts of terrestrial organic matter. Terrestrial organic matter is always being supplied to the deep ocean by bottom currents but usually is oxidized during transportation and deposition. The modern analog for the midCretaceous western North Atlantic is the Black Sea, where organic-rich sediments desposited under reducing conditions contain large amounts of terrestrially derived organic components (Simoneit, 1977; Debyser et al., 1977).

\section{Carbon Isotope Record}

The pattern of TOC distribution in the North Atlantic has been linked to the isotopic geochemistry of carbon by Scholle and Arthur (1980). They note that from the Berriasian into the Aptian-Albian there was a steady shift in $\delta^{13} \mathrm{C}$ toward more positive values in whole-rock samples of pelagic limestone (Fig. 8). The ratios drop in the Albian and rise again in the Cenomanian (Fig. 8). Because the tests of carbonate organisms are in isotopic equilibrium with seawater, Scholle and Arthur (1980) interpret their data to suggest that the surface waters of the North Atlantic gradually became isotopically heavier from the Berriasian through to the Aptian-Albian. They argue that this isotopic change was caused by the burial of marine organic matter (which is enriched relative to surface waters in ${ }^{12} \mathrm{C}$ ) beneath the reducing bottom waters of the Atlantic. Continued burial of this organic matter would lead to enrichment of surface waters in the heavier isotope ${ }^{13} \mathrm{C}$. If this interpretation is correct, it is added evidence of the presence of reducing conditions throughout the Early Cretaceous (i.e., post-Berriasian into the Aptian).

It may be significant that there is in the isotopic data a negative $\delta^{13} \mathrm{C}$ shift of short duration at the Aptian/Albian boundary (Fig. 8). Conceivably, this represents the period of oxidation during which the sediments of Subunit $4 \mathrm{c}$ were deposited. Overturn of the water column and oxidation of organic matter at the bottom by benthic organisms would be expected to interrupt the positive $\delta^{13} \mathrm{C}$ shift typical of the Earlier Cretaceous. The negative isotopic shift of the Albian-Cenomanian (Fig. 8 ) occurred at a time when bottom waters were reducing but when TOCs were not exceptionally high (Fig. 8). In contrast, the Cenomanian event of basinwide enrich- 


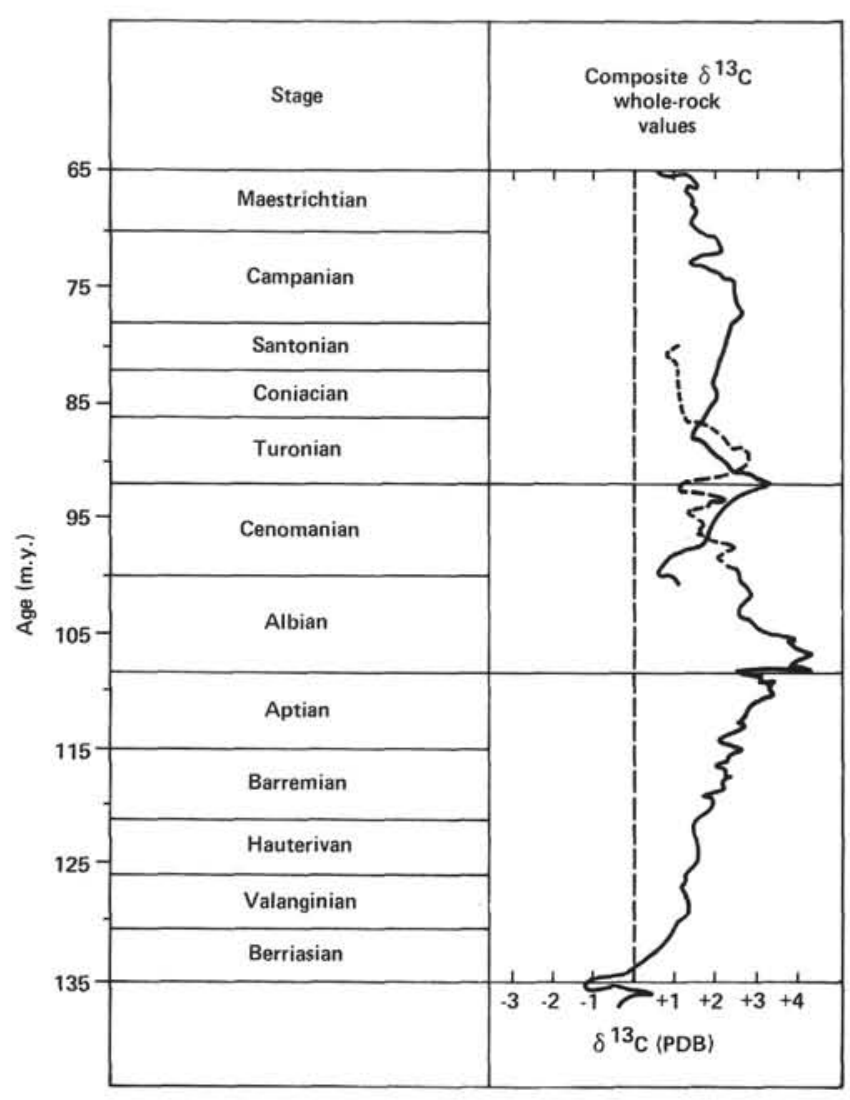

Figure 8. Carbon isotopic variation through the Cretaceous (from Scholle and Arthur, 1980).

ment in marine organic matter (Fig. 8; Summerhayes, 1981) may correlate with the positive $\delta^{13} \mathrm{C}$ shift near the Cenomanian/Turonian boundary (Fig. 8; Scholle and Arthur, 1980). One problem in trying to tie the isotopic data and the TOC data together is the poor resolution of the biostratigraphic data in carbonate-depleted middle Cretaceous sediments.

\section{Jurrassic Organic Enrichment}

The Jurassic organic-rich claystones of the Callovian (Core 125) developed because bottom waters in the early North Atlantic became temporarily poorly oxygenated or reducing (Site 534 report, this volume). Deposition took place most probably from suspension in a nepheloid layer moved by weak bottom currents (Site 534 report, this volume). The deposit is dominated by terrestrial organic matter with a subordinate marine component that is most abundant where TOCs are highest.

\section{Oceanographic Model for the Mesozoic North Atlantic}

The preceding discussions suggest that the Mesozoic North Atlantic experienced a complex circulation history that we have tried to depict in a simple and systematic fashion in Figure 9. This model does not take into account the short-term fluctuations between reducing and oxidizing conditions that occurred at intervals of 10,000 to $50,000 \mathrm{yr}$. and gave rise to the white gray or black green couplets typical of the Early and middle Cretaceous. It developed from the suggestion of Thier-

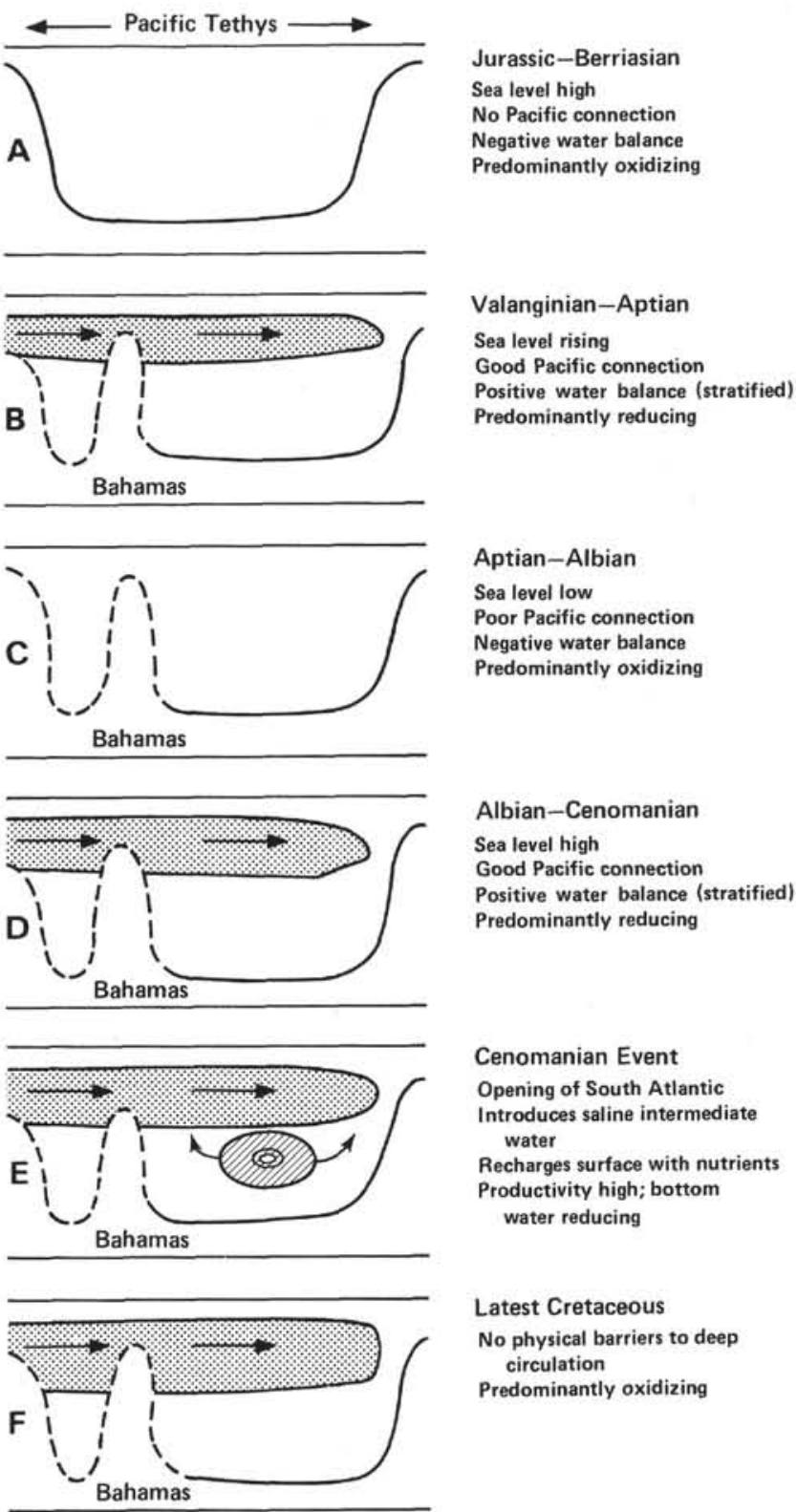

Figure 9. A-F. Simplistic schematic model depicting the relation between sea level, circulation, and development of oxidizing versus reducing bottom waters in the North Atlantic.

stein and Berger (1978) that the North Atlantic is "estuarine" with respect to the Pacific, oxygen-poor and nutrient-rich subsurface water from the Pacific being drawn into the Atlantic at intermediate depths beneath less dense surface water. Today's Gulf of California, Baltic Sea, and Black Sea are "estuarine analogs" for the Early Cretaceous North Atlantic. Movement of Pacific subsurface intermediate water from west to east may have taken place much as today in an ancestral $\mathrm{Pa}$ cific Equatorial Undercurrent. If the movement of this subsurface water had been reduced or shut off because of tectonic movements or by changes in sea level, circulation would have changed in the North Atlantic. We envisage that the connection between the Pacific and North Atlantic was poor or nonexistent in Jurassic 
through Berriasian times, during which a circulation perhaps like that of today's Mediterranean kept the Basin more or less well oxygenated (with minor exceptions, as in the Callovian) (Fig. 9A). Once the Pacific connection was established in the Early Cretaceous, a steady supply of oxygen-poor, nutrient-rich Pacific subsurface water kept North Atlantic bottom waters well stratified and poorly oxygenated (Fig. 9B) as the sea level rose (Fig. 7). We suggest that the Aptian-Albian sea-level drop (Fig. 7) cut off or reduced this supply, making the North Atlantic less well stratified and permitting a return to a negative water balance, probably like that of today's Mediterranean, which oxygenated the bottom waters (see Fig. 9C) (see Demaison and Moore, 1980, for a discussion of negative versus positive water balance). As the sea level rose, in the Albian, we surmise that the Pacific connection was reestablished or reinforced and that the North Atlantic became once more stratified and reducing (Fig. 9D). Toward the end of the Cenomanian the opening of the equatorial Atlantic allowed saline water to enter at intermediate depths from the South Atlantic (Fig. 9E); this may have caused increased advection of nutrients to the surface, leading to a basin-wide productivity event (Tucholke and Vogt, 1979; Summerhayes, 1981). An alternative explanation for the development of an organic-rich deposit of marine organic matter in the Cenomanian is that clastic dilution was very low then because of the high sea levels of that time (Fig. 7). The Early and middle Cretaceous North Atlantic Basin was disposed to become reducing, not only because of the warm climates and sluggish circulation of the Cretaceous, but also because of the unique circulation history of the Basin and the extent of the topographic barriers between it and the adjacent, better-oxidized Pacific Ocean. Today's analog for the North Atlantic in stages B and D (Fig. 9) is the Black Sea, with the Mediterranean instead of the Pacific as a nearby source of deep water. The change in state of the North Atlantic from C (oxidizing) to D (reducing) in Figure 9 mimics the change in circulation of the Black Sea as the sea level rose during the Holocene transgression (see Degens and Mopper, 1976). Both the Black Sea and the Early Cretaceous North Atlantic are silled basins in which the deposition of organic matter depended not on the fact that the basins were silled, but on their circulation history-as in other basins (Demaison and Moore, 1980). Bottom water in the Black Sea only became reducing when the Bosporus sill was deep enough to permit substantial inflow of Mediterranean deep water during the Holocene rise in sea level (Degens and Mopper, 1976).

The final stage of the evolution of the North Atlantic (Fig. 9F) involved its widening to the point where a deep circulation system vigorous enough to keep the bottom oxygenated could develop; it is not clear if Pacific inflow continued through this period, though it seems probable that it did.

During the Early and mid-Cretaceous the influx of Pacific intermediate water rich in nutrients would have led to an increase in the vertical nutrient gradient, thus, eventually, to a slow increase in the productivity of sur- face waters (through stages B and D in Fig. 9). This would explain the increase in both peak and background TOC flux from Subunits $5 \mathrm{c}$ through $4 \mathrm{~d}$ and from Subunit $4 \mathrm{c}$ into Subunit $4 \mathrm{~b}$ (Fig. 4B, 4C) as well as the Valanginian-Barremian TOC rise shown in Figure 6. It also explains why the Barremian-Aptian has a more marine organic facies than the Valanginian-Hauterivian, and may explain why the Cenomanian has a more marine organic facies than the Albian.

The development of a Mediterranean type of circulation in stage C (Fig. 9) would have led to depletion of nutrients in surface waters and to a low TOC flux in the Aptian-Albian (Subunit 4c-Fig. 4B, 4C). The organic facies would be less marine, exposing the terrestrial contribution.

We do not see in the deep western North Atlantic strong evidence for a late Barremian-Aptian "oceanic anoxic event" of the type described by Schlanger and Jenkyns (1976) and Jenkyns (1980), although there is evidence for their Cenomanian "oceanic anoxic event" (Summerhayes, 1981). Our data suggest that the deposition of organic matter in the Early Cretaceous North Atlantic Basin was not confined in time to a late Barremian-Aptian event (Figs. 4 and 6). If the event is real elsewhere in the world ocean, this lack of correspondence reflects the fact that the more or less enclosed North Atlantic Basin has a history independent of that of other nearby basins (the Pacific, for instance). The correspondence between the history of burial of organic matter in the deep North Atlantic (Figs. 4 and 6) and the $\delta^{13} \mathrm{C}$ shift in the Valanginian-Aptian (Fig. 8) suggests that processes in the North Atlantic, rather than worldwide "oceanic anoxic events," influenced the isotopic character of oceanic surface water of this Basin in the Early and middle Cretaceous.

\section{CONCLUSIONS}

Plate tectonics, paleoclimate, and eustatic changes in sea level strongly influence the organic facies of Mesozoic sediments from the deep western North Atlantic. In the Jurassic, when the North Atlantic was narrow and not connected at depth to the Pacific, bottom waters were oxidizing except for short periods of time, as in the Callovian, when they became anoxic. Organic-rich sediments from periods of anoxic bottom water have a dominantly terrestrial organic facies, suggesting low productivity.

In the Early Cretaceous, following a drop in sea level at the end of the Berriasian, a connection to the Pacific was established, permitting the influx of nutrient-rich, oxygen-poor subsurface waters. Bottom water became more or less permanently anoxic. Terrigenous influx was high near the coast (Site 534), diluting marine organic matter and supplying lesser amounts of terrestrial organic matter in its place. This influx diminished not only away from shore, but also-as sea level rosethrough time. The vertical nutrients gradient built up over the same period causing surface waters to become more productive. As a result, TOCs are highest, and the influence of marine organic matter is strongest, in the Barremian to early Aptian. 
A sea-level drop in the late Aptian cut off the influx of Pacific intermediate water. Circulation became "Mediterranean" (with a negative instead of a positive water balance) and oxidizing. Nutrient levels and productivity dropped. Terrigenous influx increased. The low supply of marine organic matter and the poor preservation of both marine and terrestrial organic materials make this period organic-poor.

Later, during the Albian rise in sea level, the Pacific connection was reestablished, bottom waters became again predominantly reducing, and surface water nutrients and productivity increased. The rate of accumulation of clastics dropped, as did the influx of terrestrial organic matter.

A further change in circulation, caused by the opening of a connection to the South Atlantic, may have taken place in the Cenomanian. It is not obvious in the sedimentary record from Sites 391 or 534 (in the data that we have examined), which leads us to suggest that its effects may have been removed by erosion from the Blake-Bahama Basin.

\section{ACKNOWLEDGMENTS}

We thank Exxon Production Research Company for permission to publish this work. R. Cunningham, P. M. Kroopnick, E-Chien Foo, and D. Gilbert provided helpful comments on the ideas presented here. TOCs were analyzed by M. S. Bisotooni of EPRCo, Rock-Eval pyrolysis was carried out by K. Hahn of EPRCo, and elemental analyses were performed by Robertson Research Inc., of Houston. T. C. Masran analyzed the organic matter types by transmitted-light microscopy.

\section{REFERENCES}

Arthur, M. A., 1979. North Atlantic Cretaceous black shales: the record at Site 398 and a brief comparison with other occurrences. In Sibuet, J.-C., Ryan, W. B. F., et al., Init. Repts. DSDP, 47, Pt. 2: Washington (U.S. Govt. Printing Office), 719-751.

Arthur, M. A., and Natland, J. H., 1979. Carbonaceous sediments in the North and South Atlantic; the role of salinity in stable stratification of Early Cretaceous basins. In Deep Drilling Results in the Atlantic Ocean: Continental Margins and Paleoenvironment: Washington, D. C. (Am. Geophys. Union), Maurice Ewing Series 3: 375-401.

Debyser, Y., Pelet, R., and Dastillung, M., 1977. Geochimie organique de sediments marins recents: Mer Noire, Baltique, Atlantique (Mauritanie). Adv. Org. Geochem. Proc. Int. Meet. 7th, 1975, Madrid, pp. 289-320.

Degens, E. T., and Mopper, K., 1976. Factors controlling the distribution and early diagenesis of organic material in marine sediments. In Riley, J. P., and Chester, R. (Eds.), Chem. Oceanogr., Vol. 6: London (Academic), 59-113.

Demaison, G. J., and Moore, G. T., 1980. Anoxic environments and oil source bed genesis. Am. Assoc. Pet. Geol. Bull., 64: 1179-1209.

Deroo, G., Herbin, J. P., Rouchaché J., and Tissot, B., 1980. Organic geochemistry of Cretaceous sediments at DSDP Holes 417D (Leg 51), 418A (Leg 52), and 418B (Leg 53) in the western North Atlantic. In Donnelly, T., Francheteau, J., Bryan, W., Robinson, P., Flower, M., Salisbury, M., et al., Init. Repts. DSDP, 51, 52, 53, Pt. 2: Washington (U.S. Govt. Printing Office), 737-746.

Donnelly, T. W., Francheteau, J., and Shipboard Scientific Party, 1980. Site 417. In Donnelly, T., Francheteau, J., Bryan, W., Robinson, P., Flower, M., Salisbury, M., et al., Init. Repts. DSDP, 51, 52, 53, Pt. 2: Washington (U.S. Govt. Printing Office), 23-350.

Gilbert, D., and Summerhayes, C. P., 1981. Distribution of organic matter in sediments along the California continental margin. In Yeats, R. S., Haq, B. U., et al., Init. Repts. DSDP, 63: Washington (U.S. Govt. Printing Office), 757-761.

, in press. Distribution, thermal alteration, and hydrocarbon potential of sediments from the Gulf of California. In Curray, J.
R., Moore, D. G., et al., Init. Repts. DSDP, 64: Washington (U.S. Govt. Printing Office).

Gilbert, D., Summerhayes, C. P., and Johnson, D. L., 1980. Nature, origin, and petroleum source potential of organic matter from deep sea drilling Sites $434,435,438$, and 440 in the Japan Trench. In Scientific Party, Init. Repts. DSDP, 56, 57, Pt. 2: Washington (U.S. Govt. Printing Office), 1327-1330.

Hochuli, D., Kelts, K., 1980. Palynology of middle Cretaceous black clay facies from Deep Sea Drilling Project Sites 417 and 418 of the western North Atlantic. In Donnelly, T., Francheteau, J., Bryan W., Robinson, P., Flower, M., Salisbury, M., et al., Init. Repts. DSDP, 51, 52, 53, Pt. 2: Washington (U.S. Govt. Printing Office), 897-936.

Jenkyns, H. C., 1980. Cretaceous anoxic events: from continents to oceans. J. Geol. Soc. London, 137:171-188.

Johnson, D. L., McIver, R. D., and Rogers, M. A., 1979. Insoluble organic matter bitumens in Leg 47 samples. In Sibuet, J.-C., Ryan, W. B. F., et al., Init. Repts. DSDP, 47, Pt. 2: Washington (U.S. Govt. Printing Office), 543-546.

McIver, R. D., 1975. Hydrocarbon occurrences from JOIDES Deep Sea Drilling Project. Proc. 9th World Pet. Congr. 1975, 2: 269-280.

McIver, R. D., and Rogers, M. A., 1978. Insoluble organic matter and bitumens in Leg 44 samples. In Benson, W. E., Sheridan, R. E., et al., Init. Repts. DSDP, 44: Washington (U.S. Govt. Printing Office), 645-649.

Masran, T. C., and Pocock, S. A. J., 1981. The classification of plant-derived particulate organic matter in sedimentary rocks. In Brooks, J. (Ed.), Organic Maturation Studies and Fossil Fuel Exploration: New York (Academic Press), pp. 145-159.

Montadert, L., and Roberts, D. G., et al., 1979. Init. Repts. DSDP, 48: Washington (U.S. Govt. Printing Office).

Schlanger, S. O., and Jenkyns, H. C., 1976. Cretaceous oceanic anoxic events: causes and consequences. Geol. Minjbouw, 55: 179-184.

Scholle, P. A., and Arthur, M. A., 1980. Carbon isotope fluctuations in Cretaceous pelagic limestones: potential stratigraphic and petroleum exploration tool. Am. Assoc. Pet. Geol. Bull., 64:67-87.

Simoneit, B. R. T., 1977. The Black Sea, a sink for terrigenous lipids. Deep-Sea Res., 24:813-830.

Summerhayes, C. P., 1981. Organic facies of middle Cretaceous black shales in deep North Atlantic. Am. Assoc. Pet. Geol. Bull., 65: 2364-2380.

Summerhayes, C. P., and Gilbert, D., 1982. Distribution, origin, and hydrocarbon potential of organic matter in sediments from the $\mathrm{Pa}$ cific margin of southern Mexico. In Watkins, J. S., Moore, T. C., et al., Init. Repts. DSDP, 66: Washington (U.S. Govt. Printing Office), 541-546.

, in press. Distribution, origin, and hydrocarbon potential of organic matter in sediments from the Pacific margin of Guatemala. In Aubouin, J., von Huene, R., et al., Init. Repts. DSDP, 67: Washington (U.S. Govt. Printing Office), 595-600.

Thierstein, H. R., 1979. Paleoceanographic implications of organic carbon and carbonate distribution in Mesozoic deep sea sediments. In Talwani, M., Hay, W., and Ryan, W. B. F. (Eds.), Deep Drilling Results in the Atlantic Ocean: Continental Margins and Paleoenvironment: Washington, D. C. (Am. Geophys. Union), Maurice Ewing Series 3:249-274.

Thierstein, H. R., and Berger, W. H., 1978. Injection events in ocean history. Nature, 276:461-466.

Tissot, B., Demaison, G., Masson, P., Delteil, J. R., and Combaz, A., 1980. Paleoenvironment and petroleum potential of middle Cretaceous black shales in Atlantic basins. Am. Assoc. Pet. Geol. Bull., 64:2051-2063.

Tucholke, B. E., and Vogt, P. R., 1979. Western North Atlantic: sedimentary evolution and aspects of tectonic history. In Tucholke, B. E., Vogt, P. R., et al., Init. Repts. DSDP, 43: Washington (U.S. Govt. Printing Office), 791-826.

Vail, P. R., Mitchum, R. M., and Thompson, S., 1977. Global cycles of relative changes of sea level. In Seismic stratigraphy. Am. Assoc. Pet. Geol. Mem., 26:83-98.

Welte, D. H., Cornford, C., and Rüllkotter, J., 1979. Hydrocarbon source rocks in deep sea sediments. Proc. Offshore Technol. Conf., 1:457-464.

Date of Initial Receipt: April 19, 1982 